\title{
PATTERNS OF CACTACEAE SPECIES DISTRIBUTION IN A PROTECTED AREA IN THE SEMIARID CAATINGA BIOME OF NORTH-EASTERN BRAZIL
}

\author{
S. Ribeiro-Silva ${ }^{1}$, M. B. Medeiros ${ }^{2}$, V. V. F. Lima ${ }^{1}, M . R \cdot$ Peixoto $^{3}$ \\ \& L. Y. S. AONA ${ }^{3}$
}

\begin{abstract}
Although Brazil is the centre with the third highest diversity of Cactaceae, the distribution of species at the local scale in Brazil remains largely unknown. This article describes the distribution patterns of the Cactaceae communities in the protected area of the Contendas do Sincorá National Forest (CSNF) in a semiarid region in the north-east of Brazil. Trails were distributed between the altitudes of 290 and $596 \mathrm{~m}$, along which 91 plots (1.8 ha) were established for quantitative surveys. The floristic data were also recorded separately on these trails. With the floristic survey, 18 taxa were recorded, and the quantitative surveys within the plots identified 10 species, represented by 1135 individuals. The distribution patterns of the species of Cactaceae were intermittent, which provided a likely explanation for the differences between the floristic survey and the species composition of the plots. The largest fraction of the floristic variation was not explained by environment or space, and this may be related to climatic alterations in the past, evolutionary processes, natural and anthropic disturbances and other unmeasured environmental variables. The recorded endemic, vulnerable and endangered species of the caatingas of Bahia indicate that broader protection areas for the Cactaceae species in the region of the CSNF are necessary.
\end{abstract}

Keywords. Endemism, environmental factors, hotspots, protected areas, Tacinga palmadora.

\section{INTRODUCTION}

Cacti are important elements of the vegetation structure in arid and semiarid ecosystems in the Americas and are used for traditional and economic purposes (Agra, 1996; Oldfield, 1997; Anderson, 2001; Hernández et al., 2001; Boyle \& Anderson, 2002; Ortega-Baes \& Godínez-Alvarez, 2006; Andrade, 2008; Lucena et al., 2013; Alanís-Rodríguez et al., 2015). The role of environmental factors as determinants of

1 Centro Nacional de Pesquisa e Conservação da Biodiversidade do Cerrado e Caatinga (CECAT), Instituto Chico Mendes; Prédio do Centro de Excelência do Cerrado; Jardim Botânico de Brasília, SMDB Cj 12 , Lago Sul, Brasília DF, Brazil. E-mail: suelma.ribeirosilva@gmail.com

2 Embrapa Recursos Genéticos e Biotecnologia, Parque Estação Biológica, Av. W5 Norte, DF 70770-917, Brasília, Brazil.

3 Centro de Ciências Agrárias, Ambientais e Biológicas, Universidade Federal do Recôncavo da Bahia (UFRB), Rua Rui Barbosa, 710, Centro, 44380-000 Cruz das Almas, Bahia, Brazil. 
the distribution patterns of cactus species has been evaluated previously (Mourelle \& Ezcurra, 1996, 1997; Godínez-Alvarez \& Ortega-Baes, 2007; Guerrero et al., 2011; Gurvich et al., 2014). Differences that are related to altitude, topography and climatic factors, such as temperature and precipitation, are the determinants of species distributions at regional scale (Mourelle \& Ezcurra, 1997; Pavón et al., 2000; Guerrero et al., 2011; Gurvich et al., 2014). The chemical and physical properties of soils are also primary predictors of the distribution of cactus species, primarily at local scale (Hernández et al., 2001, 2008; Alanís-Rodríguez et al., 2015). In addition to these determinants, patterns of cactus distribution are linked to reproductive outputs and dispersal strategies (Taylor \& Zappi, 2004).

Four centres of diversity are identified for the Cactaceae (Taylor \& Zappi, 2004). The first centre is in central Mexico and south-western USA. The second centre contains approximately $18 \%$ of the genera and is in the Andes, including parts of Peru, Bolivia, southern Ecuador and north-eastern Chile. The third centre of diversity is located in Campos Rupestres in south-eastern Brazil and in north-eastern Brazil in the Caatinga phytogeographic domain, the largest and most isolated of the 21 core areas of seasonal dry forests in the Neotropical region (Queiroz, 2006; Linares-Palomino et al., 2010). These semiarid caatingas are hotspots of Cactaceae, with high levels of species endemism (Taylor \& Zappi, 2004) in the driest climates in Brazil, characterised by 5-6 months of precipitation of $<100 \mathrm{~mm}$ and by a large proportion of deciduous species (Pennington et al., 2000).

Despite these data, the determinants of distribution of Cactaceae species have not been adequately addressed (Dutra Saraiva \& Souza, 2012), particularly at the local scale. A central question to define conservation strategies is how distribution patterns of species vary as a function of geographical space and the environment (Mourelle \& Ezcurra, 1997). Because of the vulnerability of the Caatinga biome to the unceasing impoverishment of the vegetation caused by human disturbance, such as agriculture and extractive activities, this question is a major concern (Leal et al., 2005; Ribeiro et al., 2015). In the Caatinga biome, $4956 \mathrm{~km}^{2}$ are included in protected areas, but the integral protected areas, such as national or state parks, ecological stations and biological reserves, cover $<1 \%$ of the entire region (Leal et al., 2005).

Ribeiro-Silva et al. (2011) proposed a number of studies and actions primarily related to ecological and botanical field assessments to determine more accurately the conservation status and to reduce the extinction risk of the Cactaceae species in Brazil. This article describes the distribution patterns of the Cactaceae community in a protected area in the Brazilian semiarid north-east in the Contendas do Sincorá National Forest (CSNF). This protected area is located in a hotspot region in northeastern Brazil that was selected as a conservation priority area for Cactaceae (Taylor \& Zappi, 2004). In particular, our aim in doing this study was to answer the following questions. What are the determinants of species distribution patterns of Cactaceae at a local scale within a protected area in a hotspot of cactus diversity? What is the floristic composition and structure of the Cactaceae community in this region? Are 
the environments that encompass the floristic variation of the Cactaceae within the protected area?

\section{Materials ANd Methods}

\section{Study area}

The study was conducted in the CSNF, in a semiarid region in north-eastern Brazil (Fig. 1). The CSNF was established in 1999 as a conservation unit for sustainable use (SNUC, 2002) in the Caatinga biome in the state of Bahia $\left(13^{\circ} 57^{\prime} 30^{\prime \prime} \mathrm{S}, 41^{\circ} 5^{\prime} 0^{\prime \prime} \mathrm{W}\right)$. This protected area covers 11,034 ha in the valley of the Garapa stream. The elevation varies between 220 and $550 \mathrm{~m}$ a.s.1. A small part of the CSNF (270 ha) is located in the Grotas highlands, with altitudes up to $750 \mathrm{~m}$ (Fig. 1). The climate is semiarid, with a mean annual temperature of $23^{\circ} \mathrm{C}$.

The annual precipitation ranges from 500 to $700 \mathrm{~mm}$ (Ibama, 2006), and the rainy period is from November to January. The primary soil types are lithosols, podzols and latosols (Embrapa, 2015). The vegetation is composed of the physiognomies of the Caatinga, including the forested steppe savannah and the woody steppe savannah (Veloso et al., 1992).

Before the establishment of the protected area, the CSNF area was characterised by a history of anthropogenic disturbances that were primarily related to the deforestation of woody and shrubby caatingas for timber and charcoal production (Ibama, 2006).

\section{Data collection}

The biodiversity monitoring programme of the CSNF was established by the Brazilian government environmental agency the Chico Mendes Institute for Biodiversity Conservation. This monitoring programme is composed of permanent trails and transects that are located in sites that range from 290 to $457 \mathrm{~m}$. We used these trails to locate additional plots to those that were previously established to reach altitudes above $500 \mathrm{~m}$ within the CSNF and in the surrounding areas. The locations of the additional trails were dependent on accessibility, and were based on an altitude map that was produced using a digital terrain model with $90 \mathrm{~m}$ of resolution in SIG ArcGis 9.2 (Esri, 2004). These additional trails were located between the altitudes of 290 and $596 \mathrm{~m}$. Each trail was a minimum of $2 \mathrm{~km}$ long (Fig. 1), and along these trails, 91 plots were established, with a minimum distance of $100 \mathrm{~m}$ between plots. In each $200 \mathrm{~m}^{2}(20$ $\times 10 \mathrm{~m}^{2}$ ) plot, all individuals of the family Cactaceae were recorded and identified in the dry and rainy seasons from 2012 to 2014. Most of the plots were within the CSNF, at altitudes ranging from 290 to $450 \mathrm{~m}$. The higher elevation areas up to $596 \mathrm{~m}$ were sampled within, and in the surrounding areas of, the Grotas highlands (Table 1 and Fig. 1).

To provide additional information on the floristic composition within, and in the surrounding areas of, the CSNF, the floristic data were also recorded on the identical trails but not within the plots, in accordance with the 'wide patrolling' method 


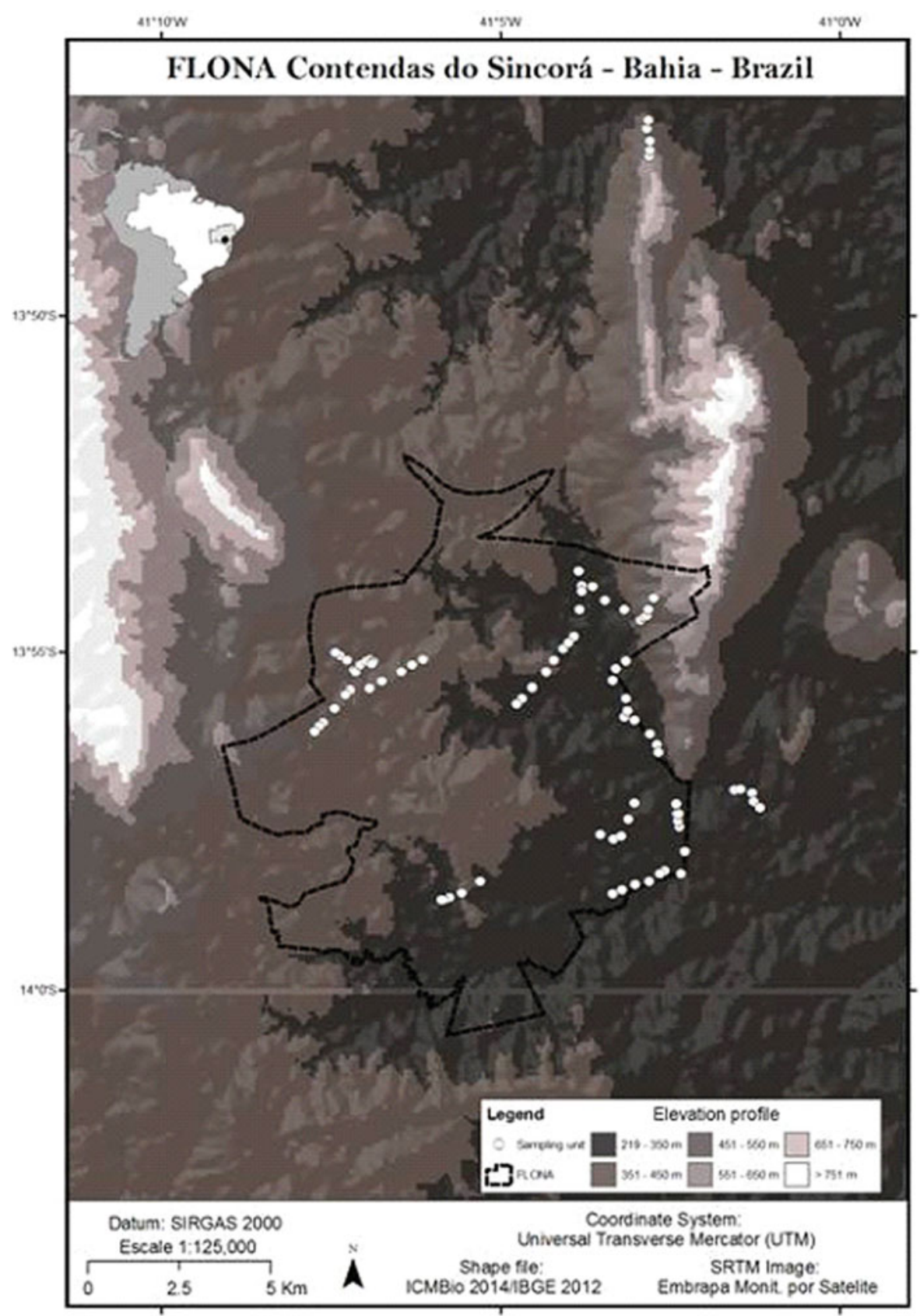

FIG. 1. Plots within, and in the surrounding areas of, the Contendas do Sincorá National Forest, Bahia, Brazil. 
TABLE 1. Mean values and standard deviations of environmental factors in the Contendas do Sincorá National Forest, Bahia, Brazil

\begin{tabular}{lllllll}
\hline \hline & $\begin{array}{l}\text { No. } \\
\text { of } \\
\text { plots }\end{array}$ & $\begin{array}{l}\text { Altitude } \\
(\mathrm{m})\end{array}$ & $\begin{array}{l}\text { Slope } \\
\left({ }^{\circ}\right)\end{array}$ & $\begin{array}{l}\text { Sum of the } \\
\text { bases } \\
\left(\mathrm{cmol} / \mathrm{dm}^{3}\right)\end{array}$ & $\begin{array}{l}\text { Clay } \\
\text { content } \\
(\mathrm{g} / \mathrm{kg})\end{array}$ & $\begin{array}{l}\text { Sand } \\
\text { content } \\
(\mathrm{g} / \mathrm{kg})\end{array}$ \\
\hline $\begin{array}{c}\text { Valley of Garapa } \\
\text { downstream }\end{array}$ & 53 & $314.2 \pm 18.7$ & $2.5 \pm 2.2$ & $2.4 \pm 2.2$ & $313.3 \pm 69.3$ & $509.2 \pm 152.1$ \\
$\begin{array}{c}\text { Valley of Garapa } \\
\text { upstream }\end{array}$ & 15 & $375.6 \pm 11.6$ & $1.5 \pm 1.0$ & $1.3 \pm 0.6$ & $308.6 \pm 96.3$ & $503.3 \pm 134.2$ \\
$\begin{array}{c}\text { Intermediate } \\
\text { highlands }\end{array}$ & 10 & $417.7 \pm 23.1$ & $3.05 \pm 1.2$ & $1.7 \pm 2.1$ & $337.5 \pm 84.3$ & $487.4 \pm 111.2$ \\
\begin{tabular}{l} 
Highlands \\
\hline \hline
\end{tabular} & 12 & $497.4 \pm 76.3$ & $13.5 \pm 10.6$ & $1.8 \pm 0.9$ & $306.2 \pm 15.5$ & $643.7 \pm 26.4$ \\
\hline
\end{tabular}

(Filgueiras et al., 1994). In this method, the linear trails were walked to record and collect new species until no further new species were recorded. The walking of linear trails ideally covered the different types of vegetation and also required estimates of species abundance (Filgueiras et al., 1994). The identifications were performed in the field by taxonomists, with the aid of specialised literature (Taylor \& Zappi, 2004). Voucher specimens were deposited in the herbarium of Embrapa Genetic Resources and Biotechnology, in accordance with the standard methodology (Mori et al., 1985). The scientific names followed the criteria of the Brazilian Flora Checklist (Zappi et al., 2015; Rio de Janeiro Botanical Garden, no date).

Three environmental factors were selected as important predictors of plant distribution patterns of the Cactaceae in arid and semiarid ecosystems at local geographical scales: soil physical-chemical parameters, altitude and slope (Mourelle \& Ezcurra, 1996; Hernández et al., 2001; Guerrero et al., 2011; Gurvich et al., 2014; Alanís-Rodríguez et al., 2015). The soil variables included sand, clay and silt, $\mathrm{pH}$ $\left(\mathrm{H}_{2} \mathrm{O}\right)$, the sum of the bases $\left(\mathrm{Ca}^{2+}, \mathrm{Mg}^{2+}, \mathrm{K}^{+}\right.$and $\left.\mathrm{Na}^{+}\right)$, the concentrations of $\mathrm{Al}^{3+}$, $\mathrm{N}$ and $\mathrm{P}^{+}$, and the carbon:nitrogen ratio. The soil samples were collected at two points within each plot at $0-20 \mathrm{~cm}$ depth. The soil samples were dried at room temperature and aggregated in one sample for physical and chemical analyses.

The slope of the terrain in each plot was measured using a Suunto PM-5/360 clinometer (Suunto, Vantaa, Finland) through measures perpendicular to the central axis. The coordinates and altitude were recorded using the GPS model GPSMap 60csx (Garmin, Olathe, Kansas, USA).

\section{Data analyses}

Principal component analysis (PCA) was used to analyse the 11 environmental variables: nine physical-chemical parameters of soil, and altitude and slope. The data were previously standardised using the standard deviation of each variable. 
The floristic composition was analysed using non-metric multidimensional scaling (NMS) and two types of ordination: the Jaccard index (the presence or absence of species) and the Bray-Curtis index (quantitative).

The PCA and NMS analyses were performed with PC Ord version 5.15 software (McCune \& Mefford, 2006).

We performed a variance partitioning procedure to assess the contribution of each of the following fractions to floristic variance: $a$, environment alone; $b$, shared contribution between environment and space; and c, space alone. The routine followed the implementation of Eisenlohr (2014), with Moran's eigenvector maps (Dray et al., 2006) as spatial variables, using the 'spacemakeR' package of $R$ environment ( $R$ Development Core Team, 2012). Both environmental and spatial variables were forward selected (Blanchet et al., 2008) using the 'packfor' package in R.

\section{RESULTS}

\section{Composition and structure of Cactaceae}

The floristic survey using the wide patrolling method recorded 18 taxa within the CSNF and in the surrounding areas: Arrojadoa penicillata (Gürke) Britton \& Rose, Arrojadoa rhodantha (Gürke) Britton \& Rose, Brasilicereus phaeacanthus (Gürke) Backeb., Brasiliopuntia brasiliensis (Willd.) A.Berger, Cereus jamacaru DC., Pereskia aureiflora F.Ritter, Pereskia bahiensis Gürke, Stephanocereus leucostele (Gürke) A.Berger, Tacinga funalis Britton \& Rose, Tacinga palmadora (Britton \& Rose) N.P.Taylor \& Stuppy, Tacinga inamoena (K.Schum.) N.P.Taylor \& Stuppy, Pilosocereus catingicola (Gürke) Byles \& G.D.Rowley, Pilosocereus pentaedrophorus (Labour.) Byles \& G.D.Rowley subsp. robustus Zappi, Pilosocereus gounellei (F.A.C.Weber) Byles \& G.D.Rowley, Melocactus concinnus Buining \& Brederoo, Melocactus inconcinnus Buining \& Brederoo, Espostoopsis dybowskii (Rol.-Goss.) Buxb. and Hylocereus setaceus (Salm-Dyck) R.Bauer. These taxa were used in an identification guide for the Cactaceae surveyed in this region of the Caatinga (Peixoto et al., 2015).

The quantitative surveys within the plots sampled 1135 individuals comprising 10 species (eight genera), and Cactaceae were recorded in 76 of the 91 plots. The most abundant species was Tacinga palmadora, with 534 individuals, or $47 \%$ of the total individuals in the Cactaceae community (Table 2). The other abundant species were Tacinga funalis (201 individuals) and Brasilicereus phaeacanthus (189 individuals), which combined with Tacinga palmadora accounted for 924 individuals, or $81.4 \%$ of the total number sampled. The least abundant species was Pereskia aureiflora, with only one individual recorded.

Most of the species that were recorded within these plots were endemic to the Caatinga biome (i.e. Arrojadoa penicillata, Brasilicereus phaeacanthus, Pereskia aureiflora, Pereskia bahiensis, Stephanocereus leucostele, Tacinga funalis and Tacinga palmadora), in addition to two endemic species from the restricted distribution areas in the caatingas from Bahia (Pereskia bahiensis and Stephanocereus leucostele) (Taylor 
TABLE 2. Number of individuals of Cactaceae recorded in 76 plots in the Contendas do Sincorá National Forest, Bahia, Brazil

\begin{tabular}{ll}
\hline \hline Species & No. of individuals \\
\hline Tacinga palmadora (Britton \& Rose) N.P.Taylor \& Stuppy & 534 \\
Tacinga funalis Britton \& Rose & 201 \\
Brasilicereus phaeacanthus (Gürke) Backeb. & 189 \\
Arrojadoa penicillata (Gürke) Britton \& Rose & 96 \\
Pereskia bahiensis Gürke & 82 \\
Melocactus concinnus Buining \& Brederoo & 52 \\
Pilosocereus catingicola (Gürke) Byles \& G.D.Rowley & 32 \\
Stephanocereus leucostele (Gürke) A.Berger & 21 \\
Cereus jamacaru DC. & 12 \\
Pereskia aureiflora F.Ritter & 1 \\
\hline \hline
\end{tabular}

\& Zappi, 2004; Rio de Janeiro Botanical Garden, no date). The abundance varied from 1 to 34 individuals per plot.

The ordination axes of the NMS for the Bray-Curtis index indicated distinct groups in the Cactaceae community (Fig. 2). In general, the pattern of species distribution was different between the Grotas highlands in the surrounding areas of the CSNF and the Cactaceae community at low altitudes in the valley. In both types of ordination, the distribution pattern of the Cactaceae community was more restricted in the areas of low altitude in the Garapa valley in which most of the species and individuals were recorded, primarily Tacinga palmadora, Tacinga funalis, Pereskia bahiensis and Arrojadoa penicillata. Some species, such as Stephanocereus leucostele, Cereus jamacaru and Pereskia aureiflora, were restricted to specific sites with fewer individuals.

\section{Soils and slope}

The first two axes of the PCA explained $33.8 \%$ and $26.5 \%$ of the total variance related to the nine physical-chemical soil variables and the slope. The axis PCA 1 described a gradient that was positively correlated with the clay and aluminium contents and that was negatively correlated with the sum of the bases $\left(\mathrm{Mg}^{2+}, \mathrm{Ca}^{2+}, \mathrm{Na}^{+}\right.$and $\left.\mathrm{K}^{+}\right)$, the sand content and the $\mathrm{pH}$. The axis PCA 2 described a gradient that was positively correlated with the silt and the $\mathrm{pH}$ and that was negatively correlated with the slope, the altitude and the aluminium ( $\mathrm{Al}^{3+}$; Table 3$)$. Therefore the soils at lower altitudes in the Garapa valley within the CSNF had higher fertility than those in areas at higher altitudes.

\section{Variance partitioning}

We did not detect a primary role of the spatially structured environmental factors on the floristic patterns. The model resulted in low explanation values (fractions $\mathrm{a}, \mathrm{b}$ and 


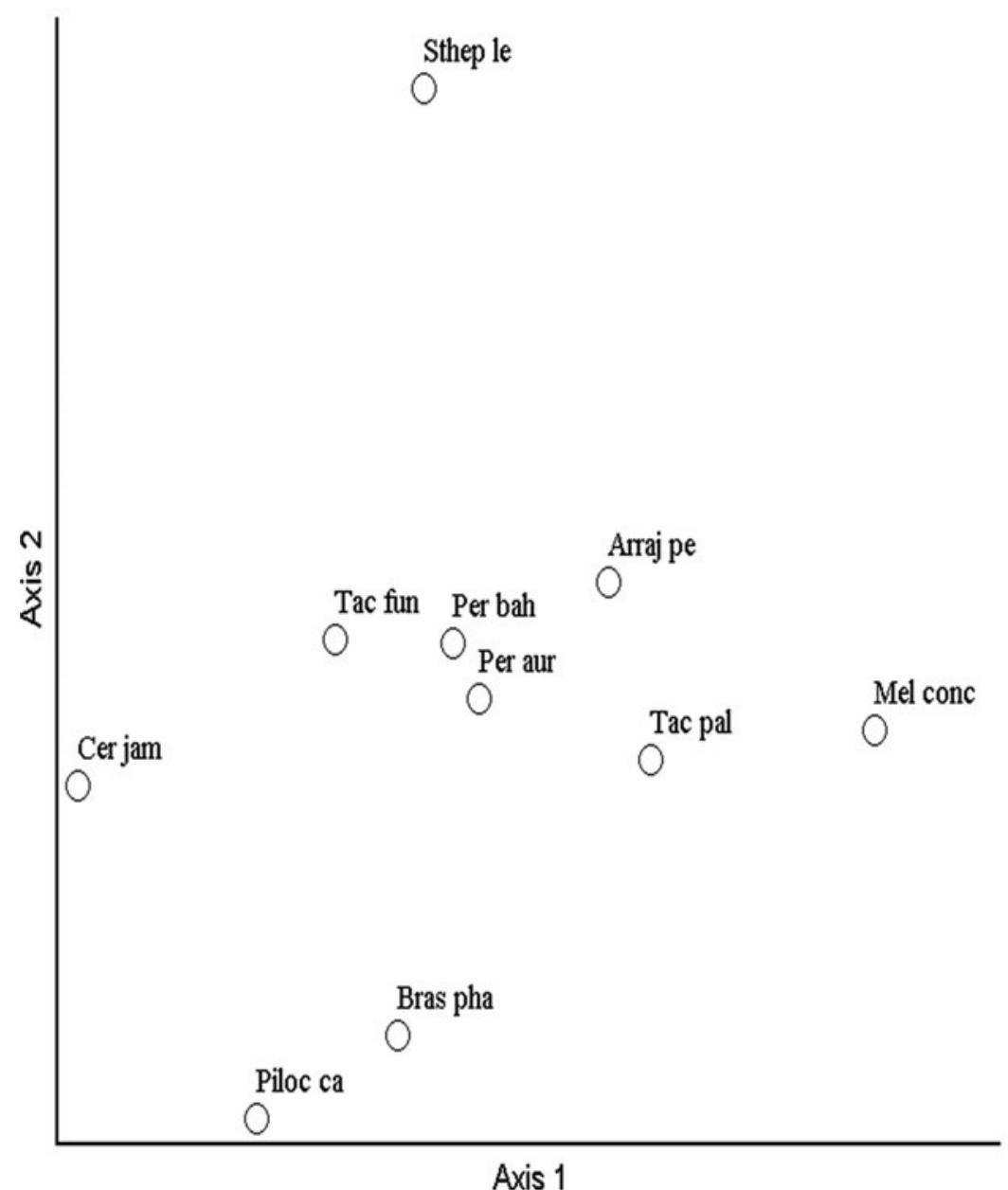

FIG. 2. Non-metric multidimensional scaling ordination analysis of 76 plots based on the floristic composition and structure of the Cactaceae with the Bray-Curtis index in the Contendas do Sincorá National Forest in Bahia, Brazil. Arraj pe, Arrojadoa penicillata; Bras pha, Brasilicereus phaeacanthus; Cer jam, Cereus jamacaru; Mel conc, Melocactus concinnus; Per aur, Pereskia aureiflora; Per bah, Pereskia bahiensis; Piloc ca, Pilosocereus catingicola; Sthep le, Stephanocereus leucostele; Tac fun, Tacinga funalis; Tac pal, Tacinga palmadora.

c), and $94 \%$ of the species distributions remained undetermined (residuals) (Fig. 3). However, the individual fractions were significant (Table 4).

\section{DiscusSiON}

The floristic survey that identified 18 species provided essential information additional to the quantitative data from the plots in which only 10 species were recorded. These differences were associated with the intermittent distribution patterns of 
TABLE 3. Correlation values of the nine physical-chemical soil variables, slope and altitude with the two first axes produced by principal component analysis (PCA) of the Contendas do Sincorá National Forest, Bahia, Brazil

\begin{tabular}{lrr}
\hline \hline Variable & PCA 1 & PCA 2 \\
\hline Sand & -0.85 & -0.37 \\
Silt & 0.63 & 0.58 \\
Clay & 0.75 & -0.03 \\
$\mathrm{pH}\left(\mathrm{H}_{2} \mathrm{O}\right)$ & -0.60 & 0.64 \\
Aluminium & 0.56 & -0.72 \\
Carbon:nitrogen & 0.21 & 0.13 \\
Phosphorus & -0.54 & 0.18 \\
Nitrogen & -0.60 & -0.55 \\
Sum of the bases & -0.81 & 0.08 \\
Slope & -0.09 & -0.68 \\
Altitude & 0.15 & -0.83 \\
\hline \hline
\end{tabular}

TABLE 4. Performance of the selected models used to explain the floristic variation

\begin{tabular}{lclll}
\hline \hline Fraction & Degrees of freedom & Variance & $F$ & $P(>F)$ \\
\hline $\begin{array}{l}\text { Environment } \\
\quad \text { Model }\end{array}$ & 1 & 0.017 & 2.90 & $0.014^{*}$ \\
$\quad$ Residual & 72 & 0.41 & - & - \\
$\begin{array}{l}\text { Space } \\
\quad \text { Model }\end{array}$ & 2 & 0.03 & 2.38 & $0.014^{*}$ \\
$\quad$ Residual & 72 & 0.41 & - & - \\
\hline \hline
\end{tabular}

${ }^{*} P<0.05$.

the Cactaceae species (Taylor \& Zappi, 2004; Hernández et al., 2008) and the rare individuals of eight species (Arrojadoa rhodantha, Brasiliopuntia brasiliensis, Tacinga inamoena, Pilosocereus pentaedrophorus subsp. robustus, Pilocereus gounellei, Melocactus inconcinnus, Espostoopsis dybowskii and Hylocereus setaceus) that were restricted to specific sites within, and in the surrounding areas of, the CSNF.

The high levels of endemic species were expected because north-eastern Brazil is a priority area for conservation efforts for endemism and species richness of Cactaceae (Taylor \& Zappi, 2004). The occurrence of two endemic species that were restricted to the caatingas of Bahia, namely Pereskia bahiensis and Stephanocereus leucostele (Taylor \& Zappi, 2004), emphasised the importance of the CSNF as a protected area for the conservation of Cactaceae species in the Caatinga biome.

A few species of Cactaceae are associated with anthropogenic disturbances, and this plant family might be an effective indicator group to establish protected areas (Taylor \& Zappi, 2004). Of the species sampled in the CSNF, only Cereus jamacaru, with a few individuals, was associated with human-disturbed environments. 


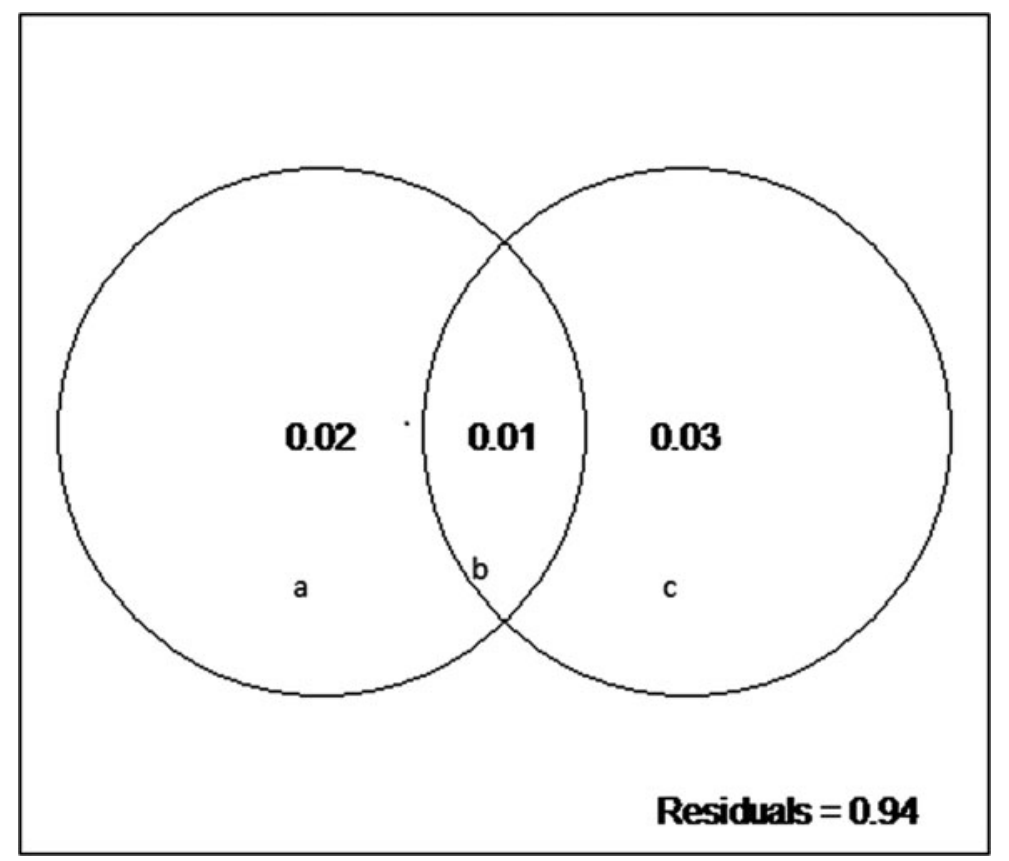

FIG. 3. Partitioning variance: a, the fraction explained solely by environmental variables; $b$, the fraction explained by spatial and environmental components; and c, the fraction explained solely by space.

The species that was the most abundant in this study, Tacinga palmadora, has a wide distribution pattern in the north-eastern Brazilian caatingas, ranging from the state of Rio Grande do Norte to southern Bahia, in addition to being endemic in this region (Taylor \& Zappi, 2004). This species, in association with the other endemic species that were typical of the caatingas, such as Tacinga funalis, Arrojadoa penicillata, Brasilicereus phaeacanthus, Pereskia aureiflora, Pilosocereus catingicola and Stephanocereus leucostele, occur in highly fragmented areas in the north-eastern Brazilian caatingas; therefore, to avoid inclusion in the category 'Endangered' in the International Union for Conservation of Nature Red List (IUCN, 2015), monitoring and protection are required (Taylor \& Zappi, 2004). Furthermore, some of the species deserve special attention because of anthropogenic threats; examples are Pereskia aureiflora, with only one individual recorded in the CSNF and classified as an 'Endangered' species; Espostoopsis dybowskii, a vulnerable species recorded only in the floristic survey in the sandstones in the northern Grotas highlands; and Pilosocereus pentaedrophorus subsp. robustus, a 'Near Threatened' species. Although more abundant than the other species requiring special attention that are also recorded in the quantitative survey, Brasilicereus phaeacanthus is also classified as an 'Endangered' species (IUCN, 2015). 
Although environmental factors are important as predictors of the composition and abundance of Cactaceae species (Hernández et al., 2001; 2008; Alanís-Rodríguez et al., 2015), the largest fraction of the floristic variation was not explained by environment or space. This unexplained fraction may be related to climatic alterations in the past (ter Steege, 2010), evolutionary processes, natural and anthropic disturbances and other unmeasured environmental variables (Terborgh \& Andresen, 1998; Bohlman et al., 2008; Higgins et al., 2011), or even biotic factors such as herbivory (Fine et al., 2004; 2006). The taxa with only a few individuals, such as Pereskia aureiflora, Pilosocereus catingicola and Stephanocereus leucostele and the eight species sampled in the floristic survey, require further studies on their areas of distribution and relationships to the environment or space. Although no unique Cactaceae community was identified in the Grotas highlands, the quantitative data and the floristic survey recorded essential data relating to some species that occurred in restricted sandstone environments in the area surrounding the CSNF, i.e. Espostoopsis dybowskii and Pilocereus gounellei.

Although seed dispersal of Cactaceae is typically through transport by bats, birds, lizards and ants, a few species are dispersed vegetatively by stem segments, such as the species of Opuntioideae (Taylor \& Zappi, 2004). This dispersal mechanism could explain the high abundance of Tacinga palmadora in comparison with the other species. This feature of dispersal could also explain the unexplained fraction of the floristic variation.

Given the endemic, vulnerable and endangered species of the caatingas from Bahia, in addition to the intermittent floristic patterns, our results indicate that broader protection areas for the Cactaceae species in the region of the CSNF are necessary. These data indicate the need specifically for a broader conservation area that would include the areas in the Grotas highlands that were associated with threatened species. Furthermore, the category of this protected area must be changed from sustainable use to integral protection to improve the outcomes of the conservation actions that are required in this region.

\section{ACKNOWLEDGEMENTS}

We thank the Fundação Flora and Coordenação de Aperfeiçoamento de Pessoal de Ensino Superior for scholarships to Victor Ferreira Lima and Mônica Peixoto, respectively; PROBIO II-ICMBio and Embrapa Genetic Resources and Biotechnology for financial support; Pedro V. Eisenlohr for support in spatial statistics; Marianna Rodrigues de Souza, Daniela Zappi and Nigel Taylor for reviewing the species list; Geraldo Machado Pereira, Head of CSNF, for logistics and technical support; and Valdeci Ferreira (Dudu), Valdemar Souza (Camarão) and Glocimar Pereira Silva for support in field activities. L.Y.S.A. acknowledges support from the Foundation for Research Support, Bahia, and the National Research Council (CNPq) in financing the project (grants RED0034/2014 and 442604/2014-9, respectively). S.R.S. acknowledges the support of PROBIO II-ICMBio in financing the project (20122014). 


\section{REFERENCES}

Agra, M. F. (1996). Plantas da Medicina Popular dos Cariris Velhos, p. 125. João Pessoa: Editora União.

Alanís-Rodríguez, E., Mora-Olivo, A., Jimenez-Pérez, J.,

Gonzalez-Tagle, M. A., Yamallel, J. I. Y. Y., Martínez-Avalos, J. G. \&

Gonzalez-Rodriguez, L. E. (2015). Composición y diversidad del matorral desértico rosetófiloendos tipos de suelo em el noroeste de Mexico. Acta Bot. Mex. 110: 105-117.

Anderson, E. F. (2001). The Cactus Family. Portland: Timber Press.

Andrade, C. T. S. (2008). Cactos Úteis na Bahia: Ênfase no Semiárido, p 125. Pelotas: USEB.

Blanchet, F. G., Legendre, P. \& Borcard, D. (2008). Forward selection of explanatory variables. Ecology 89: 2623-2632.

Bohlman, S. A., Laurance, W. F., Laurance, S. G., Nascimento, H. E. M., FEARnSIDE, P. M. \& ANDRADE, A. (2008). Importance of soils, topography and geographic distance in structuring central Amazonian tree communities. J. Veg. Sci. 19: 863-874.

Boyle, T. H. \& Anderson, E. F. (2002). Biodiversity and conservation. In: Nobel, P. S. (ed.) Cacti: Biology and Uses, pp. 125-141. Berkeley: University of California Press.

Dray, S., Legendre, P. \& Peres-Neto, P. (2006) Spatial modeling: a comprehensive framework for principal coordinate analysis of neighbor matrices (PCNM). Ecol. Modell. 196: 483-493.

Dutra Saraiva, D. \& Souza, A. (2012). Effects of environmental factors and plantation forest on endangered cactus diversity and composition in subtropical South America grasslands. Perspect. Plant Ecol. Evol. Syst. 14: 267-274.

EISENLOHR, P. V. (2014). Persisting challenges in multiple models: a note on commonly unnoticed issues regarding collinearity and spatial structure of ecological data. Braz. J. Bot. 37: 365-371.

E м B R A PA (2015). Electronic database. Online. Available: http://www.uep.cnps.embrapa.br (accessed 4 March 2015).

Es R I (2004). ArcGis 9.2. New York: Esri.

Filgueiras, T. S., Nogueira, P. E., Brochado, A. L. \& Guala II, G. F. (1994). Caminhamento: um método expedito para levantamentos florísticos qualitativos. Cadernos de Geociências 12: 39-43.

Fine, P. V. A., Mesones, I. \& Coley, P. D. (2004). Herbivores promote habitat specialization by trees in Amazonian forests. Science 305: 663-665.

Fine, P. V. A., Miller, Z. J., Mesones, I., Irazuzta, S., Appel, H. M., Stevens, M. H. H., Sä̈̈Ksü̈rvi, I., Schultz, J. C. \& Coley, P. D. (2006). The growth-defense trade-off and habitat specialization by plants in Amazonian forests. Ecology 87: S150-S162.

Godínez-Alvarez, H. \& Ortega-Baes, P. (2007). Mexican cactus diversity: environmental correlates and conservation priorities. Bol. Soc. Bot. México 81: 81-87.

Guerrero, P. C., Duran, A. P. \& Walter, H. E. (2011). Latitudinal and altitudinal patterns of the endemic cacti from the Atacama desert to Mediterranean Chile. J. Arid Environ. 75: 991-997.

Gurvich, D. E., Zeballos, S. R. \& Demaio, P. H. (2014). Diversity and composition of cactus species along an altitudinal gradient in the Sierras del Norte Mountains (Cordoba, Argentina). S. Afr. J. Bot. 93: 142-147. 
Hernández, H. M., Gómez-Hinostrosa, C. \& Bárcenas, R. T. (2001). Diversity, spatial arrangement, and endemism of Cactaceae in the Huizache area, a hot-spot in the Chihuahuan Desert. Biodivers. Conserv. 10: 1097-1112.

Hernández, H. M., Goettsch, B., Gómez-Hinostrosa, C. \& Arita, H. T. (2008). Cactus species turnover and diversity along a latitudinal transect in the Chihuahuan Desert Region. Biodivers. Conserv. 17: 703-720.

Higins, M. A., Ruokolainen, K., Tuomisto, H., Llerena, N., Cardenas, G., Phillips, O. L., VÁsquez, R. \& R ÄSÄnen, M. (2011). Geological control of floristic composition in Amazonian forests. J. Biogeogr. 38: 2136-2149.

I в а м а (2006). Plano de Manejo da Floresta Nacional Contendas de Sincorá. Brasília: Instituto Brasileiro do Meio Ambiente e dos Recursos Naturais Renováveis.

I U CN (2015). The IUCN Red List of Threatened Species, Version 2014-3. Online. Available: http://www.iucnredlist.org/ (accessed 4 March 2015).

Leal, I. R., Silva, J. M. C., TA ba Relli, M. \& Lacher Jr, T. E. (2005). Changing the course of biodiversity conservation in the Caatinga of Northeastern Brazil. Conserv. Biol. 19: 701-706.

Linares-Palomino, R., Kvist, L. P., Aguirre-Mendoza, Z. \& Gonzales-InCA, C. (2010). Diversity and endemism of woody plant species in the Equatorial Pacific seasonally dry forests. Biodivers. Conserv. 19: 169-185.

Lucena, C. M., Lucena, R. F. P., Costa, G. M., Carvalho, T. K. N., Costa, G. G. S., Alves, R. R. N., Pereira, D. D., Ribeiro, J. E. S., Alves, A. B., Quirino, Z. G. M. \& Nunes, E. N. (2013). Use and knowledge of Cactaceae in Northeastern Brazil. J. Ethnobiol. Ethnomed. 9: 62.

MCCune, B. \& MefFord, M. J. (2006). PC-ORD. Multivariate Analysis of Ecological Data, Version 5.15. Gleneden Beach: MjM Software.

Mori, S. A., Silva, L. A. M., Lisboa, G. \& Coradin, L. (1985). Manual de Manejo do Herbário Fanerogâmico, p. 97. Ilhéus: Centro de Pesquisas do Cacau.

Mourelle, C. \& Ezcurra, E. (1996). Species richness of Argentine cacti: a test of some biogeographic hypotheses. J. Veg. Sci. 7: 667-680.

Mourelle, C. \& Ezcurra, E. (1997). Differentiation diversity of Argentine cacti and its relationship to environmental factors. J. Veg. Sci. 8: 547-558.

Old field, S. (comp.) (1997). Cactus and Succulent Plants - Status Survey and Conservation Action Plan. IUCN/SSC Cactus and Succulent Specialist Group. Gland: International Union for Conservation of Nature.

Ortega-Baes, P. \& Godínez-Alvarez, H. (2006). Global diversity and conservation priorities in the Cactaceae. Biodivers. Conserv. 15: 817-827.

Pavón, N. P., Hernández-Trejo, H. \& Rico-Gray, V. (2000). Distribution of plant life forms along an altitudinal gradient in the semi arid valley of Zapotitlán, México. J. Veg. Sci. 11: 39-42.

Peixoto, M. R., Lima, V. V. F., Ribeiro-Silva, S., Medeiros, M. B., Zappi, D. C. \& Aona, L. Y. S. (2015). Electronic database. Online. Available: http://fieldguides.fieldmuseum.org n\# 684 (accessed 8 August 2015).

Pennington, R. T., Prado, D. E. \& Pendry, C. A. (2000). Neotropical seasonally dry forests and quaternary vegetation changes. J. Biogeogr. 27: 261-273.

QueIRoz, L. P. (2006). The Brazilian caatinga: phytogeographical patterns inferred from distribution data of the Leguminosae. In: Pennington, R. T., Lewis, G. P. \& R Atter, J. A. (eds) Neotropical Dry Forests and Savannas, pp. 113-149. Edinburgh: Royal Botanic Garden Edinburgh.

R Development Core Team (2012). R: A Language and Environment for Statistical Computing. Vienna: R Foundation for Statistical Computing. 
Ribeiro, E. M. S., Arroyo-Rodriguez, V., Santos, B. A., Tabarello, M. \& LEA L, I. R . (2015). Chronic anthropogenic disturbance drives the biological impoverishment of the Brazilian Caatinga vegetation. J. Appl. Ecol. 52: 611-620.

Ribeiro-Silva, S., Za p pi, D., Taylor, N. \& Machado, M. (orgs) (2011). Plano de Ação Nacional para a Conservação das Cactáceas. Série Espécies Ameaçadas No. 24, p. 112. Brasília: ICMBio.

Rio de Janeiro Botanical Garden (no date). List of Species of the Brazilian Flora. Online. Available: http://floradobrasil.jbrj.gov.br/ (accessed September 2015).

Sistema Nacional de Unidades de Conservação (SNUC) (2002). Lei. N. 9.985 de 19 de julho de 200 e Decreto No. 4.340, de 22 de agosto de 2002.

TAy Lor, N. \& ZA P Pi, D. (2004). Cacti of Eastern Brazil. Richmond: Royal Botanic Gardens, Kew.

Ter Steege, H. (2010). How neutral is ecology? Biotropica 42: 631-633.

Terborgh, J. \& Andresen, E. (1998). The composition of Amazonian forests: patterns at local and regional scales. J. Trop. Ecol. 14: 645-664.

Veloso, H. P., Rangel-Filho, A. L. R. \& Lima, J. C. A. (1992). Classificação da Vegetação Brasileira, Adaptada a um Sistema Universal. Rio de Janeiro: IBGE.

Zap pi, D., TAylor, N., Machado, M. \& Santos, M. R. (2015). Cactaceae. In: Lista de Espécies da Flora do Brasil. Jardim Botânico do Rio de Janeiro. Online. Available: http://floradobrasil.jbrj.gov.br/jabot/floradobrasil/FB70 (accessed 1 March 2015).

Received 31 August 2015; accepted for publication 26 January 2016 